\title{
A potential reference material for in situ U-Pb dating of Columbite-tantalite
}

\author{
KeJUN Hou, QIAN WANG, FAN HuANG, \\ AND DENGHONG WANG
}

MNR Key Laboratory of Metallogency and Mineral Assesment, Institute of Mineral Resources,Chinese Academy of Geological Sciences, Beijing, 100037. Kejunhou@126.com

Columbite-tantalite minerals have high $U$ contents associated with low $\mathrm{Pb}$ common contents, is a suitable mineral for direct dating of relative ore minerals. in situ techniques like laser ablation inductively- coupled plasma mass spectrometry (LA-ICP-MS) have been widely used over the last decade years to date columbite-tantalite minerals. But, at present, there is still only Coltan 139 as reference material to correct matrix effect for LA-ICP-MS analysis. During our daily analysis, we found a fairly homogeneous coltan KKTH-002 with an concordia age of $203.3 \pm 1.1 \mathrm{Ma}(\mathrm{N}=67)$. it is a potential reference material for in situ U-Pb dating of Columbite-tantalite.

\section{Reference:}

Che, X.D., Wu, F.Y., Wang, R.C., Gerdes, A., Ji, W.Q., Zhao, Z.H., Yang, J.H., Zhu, Z.Y., 2015. In situ U-Pb isotopic dating of columbite-tantalite by LA-ICP-MS. Ore Geol. Rev. 65, 979-989.

Gäbler, H.E., Melcher, F., Graupner, T., Bahr, A., Sitnikova, M.A., Henjes-Kunst, F., Oberthur, T., Bratz, H., Gerdes, A., 2011. Speeding up the analytical workflow forcoltan fingerprinting by an integrated mineral liberation analysis/LA-ICP-MS approach. Geostand. Geoanal. Res. 35, $431-448$ 